\title{
ELECTRICAL AND MAGNETIC PROPERTIES OF THE ENERGY SAVER CORRECTION ELEMENTS*
}

M. Johnson, A. McInturff, R. Raja, and P. Mantsch

August 1983

* Submitted to the $12 \mathrm{th}$ International Conference on High Energy Accelerators, August 11-16, 1983, Fermilab, Batavia, IL 60510 . 
Electrical and Magnetic Proporties of

the Energy" Sayer Correction Elements

M. Johnson. A. MeInturff, R. Faja, and P. M. Mantsch

Fermi National Accelerator Laboratory*

P.O. Box 500

Batavia, IIIInois 60510

\section{Abstract}

The lattice of the Fermi Nattonal Accelerato Laboratory"s Energy Saver/Doubler contains a group of superconducting correction windings associated with each quadrupole. These are housed in an element referred to as a "spool". There are 192 spools in the ring plus 12 special power spools which contaln the main buss 5000 ampere power input as well as correction elements. There will be constructed and tested 290 spools, including spares of each of the elght different types. There have been 260 individual spools tested to date. The spools were tested for A magnetic field quality, harmonic moments, transfer constants and coll angles, B) high voltage integrity, C) critlcal transport current, and D) cryogenic operating charecteristics (1.e. heatloads, themometry callibration checks, etc.) Data are summartzed for 318 cryogenlc tests and magnetic fleld quality of the 266 different spools, which contain 1614 correction magnet colls.

\section{Introduction}

The elght different Ensrgy Saver/Doubier spool types are deslgnated by the notation TSA-000 (Tevatron spool Type "A", serial number 000). The dffferent types are issted in Table $I$. There are four categories of correction packages, DSQ (Dipole, Sextupcle and Quadrupole); OSQ (Cctupcle, Sextupole and cuadrupole); DEQ (Dipole horizontal, Dipole Vertical and Quadrupole); and DD (Dipoie Horizontal and Dipole Vertical).

TABLE I

\section{SPOOL CORRECTION ELEMENTS SERIES}

\begin{tabular}{l} 
SPOOL DSQ COILS (UP) \\
TYPE INNER MID OUTER COILS (DOWN) \\
\hline
\end{tabular}

\begin{tabular}{|c|c|c|c|c|c|}
\hline IYPE & INNER & MID OUTER & INNER & MID & DUTER \\
\hline & & DSQI & & & \\
\hline $\boldsymbol{A}$ & $2 \mathbf{P}$ & $\begin{array}{l}\text { 6P } 4 P \\
\text { DSQII }\end{array}$ & MONE & & \\
\hline B & $s-2 P$ & $6 \mathrm{P} 4 \mathrm{P}$ & NONE & & \\
\hline C & $2 P$ & $\begin{array}{l}\text { DSQI } \\
\text { हP 4P } \\
\text { DSQII }\end{array}$ & $\frac{O S Q I}{B P}$ & $\begin{array}{l}S-6 P \\
\text { OSQI }\end{array}$ & $S-4 P$ \\
\hline D & $S-2 P$ & $\begin{array}{l}\text { 6P } 4 P \\
\text { DSQI }\end{array}$ & $\begin{array}{l}8 \mathrm{P} \\
\text { OSQI I }\end{array}$ & $\overline{s-6 P}$ & $s-4 P$ \\
\hline $\mathbf{B}$ & $2 P$ & $\begin{array}{l}\text { 6P 4P } \\
\text { DSQII }\end{array}$ & $\overline{8 P}$ & $\begin{array}{l}\text { 6P } \\
\text { OSQI I }\end{array}$ & $4 P$ \\
\hline $\mathbf{F}$ & $S-2 P$ & $\begin{array}{l}\text { 6P } \\
\text { DSQR }\end{array}$ & $\begin{array}{l}\overline{8 P} \\
\text { osQIII }\end{array}$ & $\overline{6 P}$ & $4 P$ \\
\hline 0 & $2 P$ & $\begin{array}{l}\overline{6 P} 4 \mathrm{P} \\
\mathrm{DDQ} \text { COILS } \\
\overline{\mathrm{DDQI}}\end{array}$ & $\overline{B P}$ & $6 P$ & $s-4 P$ \\
\hline H & $2 P$ & $\begin{array}{l}S-2 P \text { PP } \\
D D I\end{array}$ & NONE & & \\
\hline Low & & $\overline{2 P} \quad S-2 P$ & & & \\
\hline
\end{tabular}

S-Skew - Notes: 2P-Normal Dipole (Horizontal Bend)

-Operated by Unlversitles Research Inc.. under contract with the U.S. Dept. or Energy.
An arbltrary magnet ic fleld in two dimenslons can be represented as:

$$
B=\sum_{k} 1 c_{k} k^{*-1}
$$

where $w=x+1 y, \quad 1-\sqrt{-1}$ and $G w$ is the harmontc amplitude for Fole $2 k: k=1$ for a Dlpole, 2 for a quadrupole, ete. $G$ is dependent on parameters such as magnetic length and excltation current. This dependence can be removed by defining the harmon:s moment as:

$$
\mathrm{Mk}=\mathrm{Gk}_{\mathrm{CpR}}
$$

Here $G$ is the harmenic amplitude of the primary pole (the p8le determized) by the coll configuration), $G_{k}$ is the amplitude of any other pole and $R_{0}$ is a rêference radius which is 1 inch. If $k=1$ and $P=2$, $M$ would be the quadrupole field present in a sextupole coll. Since $G_{k}$ is in general complex, $M_{k}$ is also complex. The normal hemmonic amplitude is defined as the real part of $M$ and the skew harmonic amplitude is defined as the imaginary part.

The primary magnetic fleld measurement was at room temperature with cross checks at low tmperature. The magnetic field is measured by a Morgan coil connected to a lock-in amplifler. The Morgan coil has two sets of windings for poles two through eight. The second set is displaced by $\pi / 2 K$ radians from the first set ( $2 k$ is the fole number) so one set measumes the nortial harkonics and the other set measures the skew harmonics. To make a measurement, the magnet coii is powered at low current (a tew hundred milliamps) by an 11 hertz oscillator and a Morgan coll is motated through one revolution in 64 steps. At each step potin the driving current and the Morgan coil voltage are measured. The harponic arplitudes are determined by a Fourter transform of tine data. In order to save time, all of the Morgan coils except the one corresperding to the primary pole of the magnet are connected in series. The Individual harmonic amplitudes are then determined by Fourier analysis.

Three elements in a given coll package means that there are rour posstble polarity comblnations and an infinity of Lorentz force patterns (vector cross-products of currents and flelds to obtain the resulting forces) as the colls are ramped. Each coti package must operate in all iour polarity comblnations at the maximum operating current without quenching.

The Tevatron spool types $B, D$, and $F$ contain palrs of "safety" leads which will carry a $5000 \mathrm{~A}$ current for a short time to bypass a quenching string of main magkets so the machine may be ramped down without depositing the stored energy of the entire magnet ring into the cryogenic environment. The apools also contain two carbon resistors which act as low temperature thermometers for cryogenlc monltoring of the liquid nelium. The thermometer callbration is cross checked in the assembled spool. An Insulating vacuum compartmentalizing barrier and beam tube vacuum measuring ports, are also located in the spools. The maln buss quench stopper and assoclated voltage taps (2). are located in the single phase helium box of the spool. The Punction of the quench stopper is to prevent a quench from moving from one cell to another 
alone the main buss or starting at a sarety lad. Many of tre, as yet, only partlally understood problems of operailng a superconducting accelerator w111 be overcome by the versatility and performance range of the correction coll packages.

\section{Performance}

The typlcal cold magnetic fleld values are given In Table II. The speclficatlons and procedure for spool tests of electrical and cryogentc performance are Biven in Rer. 3.

Table II

Magnet1c Fleld Strength And Inductance* I (Coll) $=50$ Amps Measurement Radius $=\frac{2.54}{2 m}$

\begin{tabular}{|c|c|c|c|c|c|c|c|c|c|c|c|}
\hline . & D & $\mathbf{s}$ & $\theta$ & 0 & $s$ & $\theta$ & D & D & $Q$ & D & D \\
\hline$T-m$ & .475 & .157 & .19 & .08 & .112 & .19 & .475 & & .19 & .712 & \\
\hline 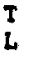 & .62 & .19 & .25 & .11 & .15 & .25 & .62 & 73 & 25 & 1.05 & \\
\hline & 55 & 603 & 489 & 221 & 390 & 489 & 755 & & 489 & 600 & \\
\hline
\end{tabular}

Figures 1 to 6 show SBdl histograms at $11 \mathrm{~Hz}$ for varlous colls used in the spool pleces. The spread in the transfer constant data is the result of manufacturing error and long term orfft in the measuring apparatus. The latter can be corrected (to about the $0.5 \%$ level) by fitting the transfer constants of all the colls in a spool piece to a standard set of values. Since measuring system drift wil affect all coils equally, any deviations from the It w11 represent manufacturing errors. The deviations from the fitted data appear in Elgures 1-6.

Figures 7 and 8 show the transfer constant measured as a function of frequency at $4.2 \mathrm{~K}$ for $5 p o o l$ 230 and the upstream part of Spool 157. The data from Shz and up was taken with apparatus similar to that used for normal room iemperature measurements. The zero frequency data was obtained by powering the magnet coil (50 Amps) at full current and then rotating the Morgan coil at constant angular velocity. The Morgan coil signal was amplified by a linear amplifter and integrated with a computer. The rocm temperature point at 11 Hertz is also plotted. The agreement between the tho measurement systens is quite good.

A Imple eddy current model of these colls shows that the Morgan coil signal that is in phase with the driving signal has the following form:

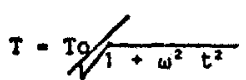

Where to is the value of the transfer constant at zero frequency. $\omega$ is the driving frequency, and $t$ is the tioe constant for the eddy current clrcuit. The solid IInes in FIgures 7 and 8 are the best fit to the data. The "t" can also be determined by measuring the ratto of the In-phase to the 90 degree out- of-phase signal with a lock-in amplifier. These results are summarized In Table III. The model appears to be correct to pirst order (factor of two).

A11 the colls of a package, at 4.6K, are Individually powered to $75 \mathrm{~A}$. They are then powered in various polarity permutations, a maximum current of 60 amperes inltially in each element. Qualiflation means that no element quenches during these polarity pormutations at the quallfying current.
There are 77 electrical moasurements made on the typlcal spool, not incluting supercenduceling measuremonts or approximately 25,000 measurements have been taken. (This number does not include those taker by "Quality Control" durlne ratrication).

TABLE III

Eddy Current Ilme Constant $\left(10^{-3}\right)$ Sec.

Constant Transer $\frac{\text { inPhase/0ut of Phase }}{\text { Signal From Lock-tn }}$

$\begin{array}{lll}\text { Spool } & \text { 230 } & \\ \text { Quadrupole } & 4.2 & 2.5 \\ \text { Dipole } & 7 & 3.7 \\ \text { Sextupole } & 1.9 & 1.65 \\ \text { Octupole } & 1.2 & \\ \text { Spool } & 157 & \\ \text { Quadrupole } & 6.1 & 3.7 \\ \text { Dipole } & 9.9 & 4.2 \\ \text { Sextupole } & 3.9 & 3.0\end{array}$

The summary of the tegt resuits for 319 spool tests were: 16 spools falled the high voltage Insulation test between correction colls or correction coll to ground; 16 spools falled the high voltage insulation test between main $(5000$ A) busses or to ground; 31 cotls out of 1614 individual coils tested falled to qualify at operational superconducting current, (because of a large redundancy of coils in the spools only 12 spools were rejected). During the 40 spool piece Test Facllity runs completed, there have been 5,090 quenches on 3.15 quenches per correction magnet which can be distributed to 6.0 quenches in the average coll from the DDQ package, 3.64 quenches from a coli in a DSQ package, and 2.7 quenches from a coll in an OSQ package. The average quallfying current for the various packages are 58.4 amperes for the OSQ package, 55.3 amperes for the DSQ packages, and 56.5 amperes for the DDQ package.

The heat load data is sumarized in rable IV.

\section{Table IV}

Spool Heat Load (Natts) at 4.2K, with a Lead Tower Gas Flow of 32 of helium (STP)

$$
\begin{aligned}
& \text { TSA }-3.2 \pm .5 \text { watts } \\
& \text { TSB }-5.3 \pm .5 \text { watts } \\
& \text { ISC }-5.3 \pm .5 \text { watts } \\
& \text { TSD }-7.4 \pm .5 \text { watts } \\
& \text { ISE }-5.3 \pm .5 \text { watts } \\
& \text { TSF }-7.4 \pm .5 \text { watts } \\
& \text { TSH }-11.2 \pm 1.0 \text { watts* }
\end{aligned}
$$

* (This is with a $5 \mathrm{kA}$ power lead gas flow of $266 \mathrm{cf}$ hellum (STP) for the pair $[0.374 \mathrm{~g} / \mathrm{sec}]$ ).

The energy lossicycle for a typlcal correction coll measured electrically" is approximately 17 joules where less than a fraction of a joule can be accounted for by eddy current loss?

The correction coll packages are installed in the accelerator with the magnetic center on the beam axis and the upstream quadrupole fleld perpendtcular to the " $x$ " (horizontal) axis. This is called the ring coordinate system and all harmonics and coll angles have been transformed into this system. Note that in transforming the harmonics to the ring system, it is 
assumed that, all the harmonics above octupole are zero except for the dipole coll where poles up to decapole are considered.

Figures 9-41 contain histograms of the various harmontes for each correction coll type. The title glves the primary pole, the harmonte number and whether it is skew or normal. All data is in the ring coordinate system. For insiance, Figure 23 is the normal octupole harmonto of the quadrupole coll.

111 of the colls that have the same dimenslons are grouped together. In particular, this included the two different length sextupale colis. In this case, the harmonlc amplitudes are cifferent, but their hardonic moments are the same.

Some of the colls are mounted in the skew position and some in the normal position. Thus, in the ring coordinate system, a skew quadrupole wlll have $100 \%$ skew quadrupole (since $G_{,} G=1$ ) and almost zero normal quadrupole. Since both ptypes of quads are grouped together, one would expect a peak at 1 for the skew quadrupole moment from the skew quadrupole colls, and a peak at zero from the rormal coils, as shown in Flgure 20. Elgure 19 shows the reverse case. This effect can also be seen in Figures 41 and 42 . The Dipoles have a $-0.2 \%$ decapole component due to their geometry. Therefore, skew Dipoles will rave a $-0.2 \%$ skew component and normal ones will have zero skew component.

As mentioned above, the correction element packages are centered on the sextupole. Since the center of the sextupole is defined as the point where the magnetic field is zero, the quadrupole field will be Identically zero.

Figures 43-48 are the histograms of the argles of the varlous coils with respect to the quadrupole coil. Thus Figures 43 and 45 give the relative alignment of the cotls in a Dipole-Sextupole-Quacrupole packaze. Figure 46 gives the relative alignment of the upstream and cownstreac packages. The large angles are from early production runs before an electronic alignment system was installed.

\section{Acknowledgements}

The Engineers and technical people who constructed the spools in such a timely fashion with great care under the direction of $\mathrm{Mr}$. D. Smith and enabled this data to be obtained - a rote of thanks.

1. M. Kuchnir, A. J. Halker, W. B. Fowler, and P. M. Mantsch, IEEE Transactions on Nuclear Sclence, (198i), Vol. NS-28, No. 3, p. 3325.

2. D. Clazynsk1, P. Mantsch, IEE Transactions on Nuclear Sclence, $(1981)$, Vol. NS-2B, No. 3 , p. 3275 .

3. A: D. McInturfe, M. Kuchnir, \& P. Mantsch, "Cryogenle Correction Coli Testing", 1983 Particle lccelerator Meeting Proceedings, Santa Fe, New Mexico

4. R. Shafer. Private Communication (Internal Memo), Ferml National hccelerator Laboratory, (1981).

5. R. Snafer, "Eddy Currents. Dispersion Relations and Iranslent Effects in Superconducting Magnets", Technlcal Memo 991, Ferml Natlonal Accelerator Laboratory, September, 1980.

6. A. D. MeInturfe, D. Gross, IEEE Transactions of Nuclear Sclence, (Nune, 1981) Yol. NS-28, No. 3 , p. 3211.

7. R. Shafer, Private Comunlcation (Internal Memo). Fermi National Accelerator Laboratory, January, 1982.

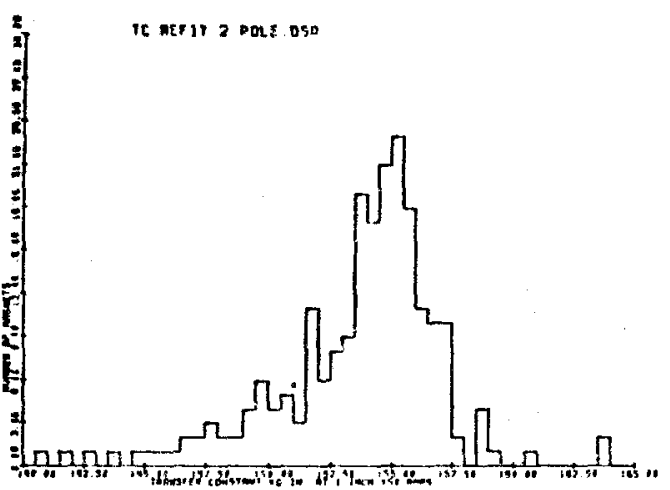

Figure 1: SBdI - Dipole DSQ Package

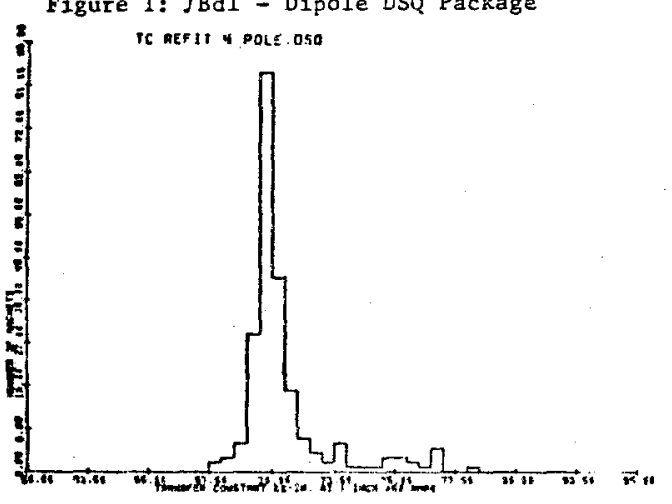

Figure 2: SBd1 - Quadrupole (1 in.) DSQ Package

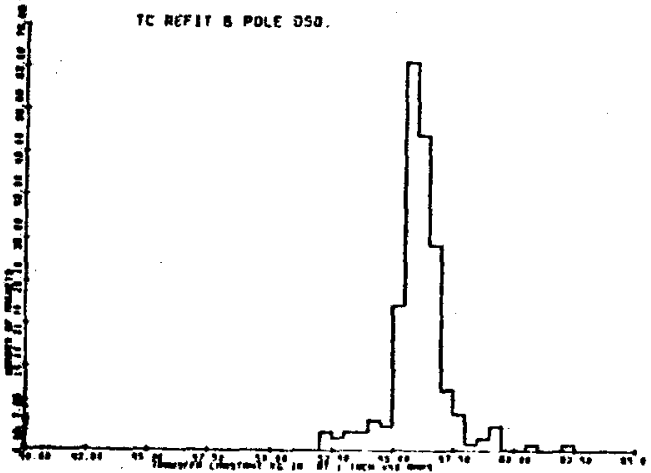

Figure 3: SBd1 - Sextupole (1 in.) DSQ Package

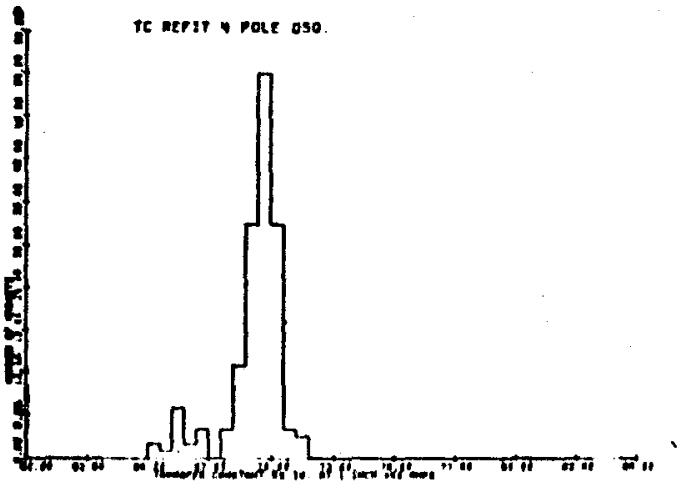

FIgure 4: JBdl - Quadrupule (l In.) OSQ Package 


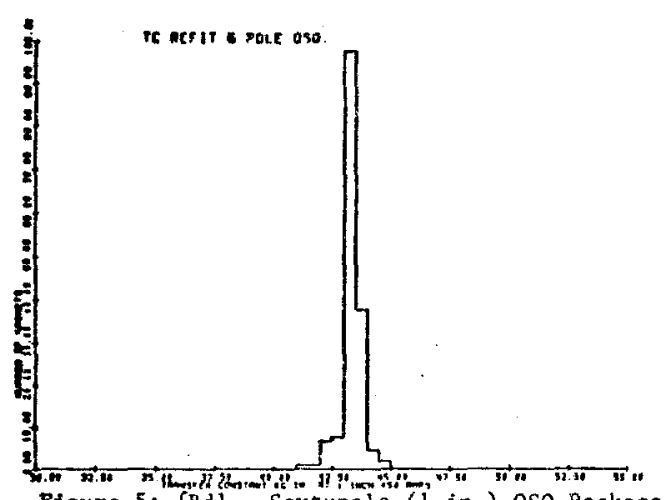

Figure 5: JBd1-Sextupole (1 in.) OSQ Package

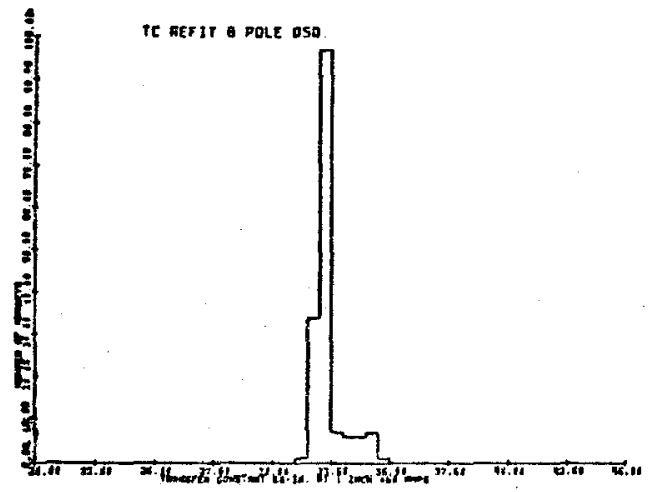

Flgure 6: SBd1 - Occupole (1 in.) OSQ Package

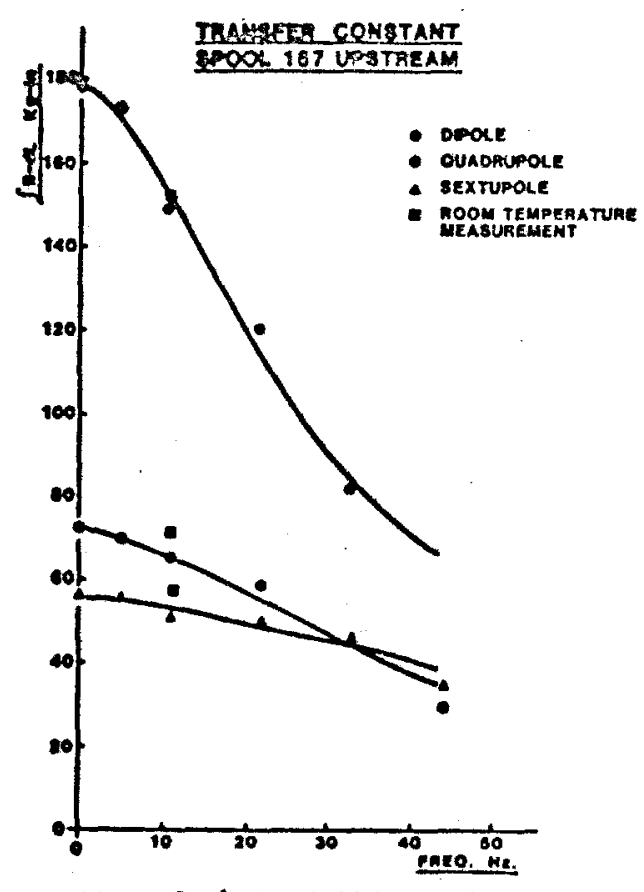

TIgure 7I fBdl - 4.2K DSQ Package

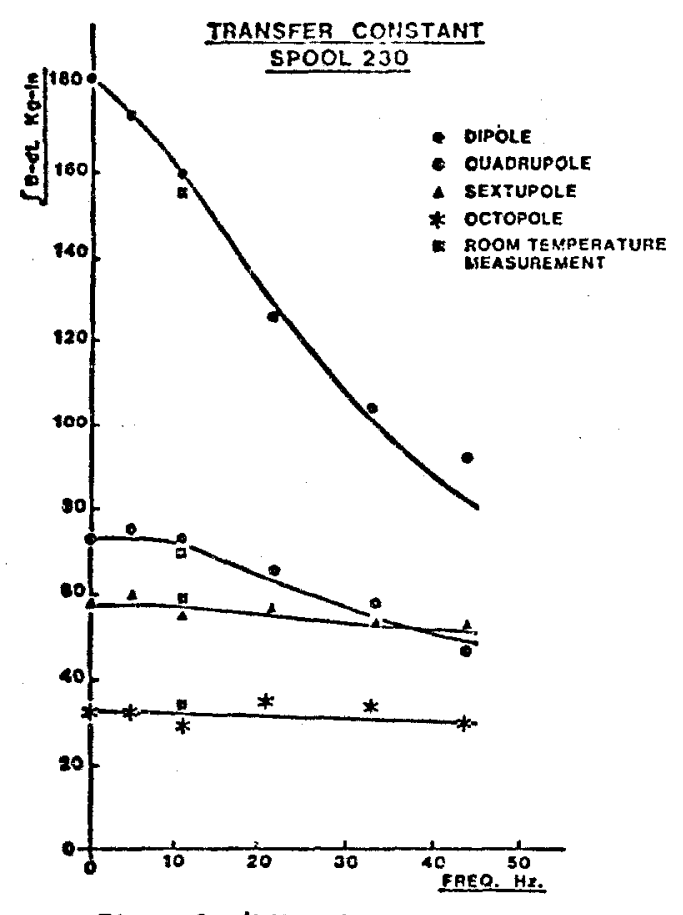

Figure 8: JBdl - 4.2K - Both Packages

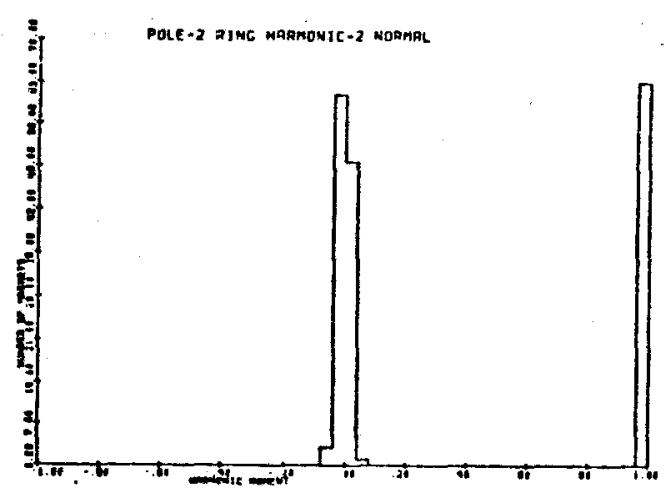

Figure 9: Dipole moment of dipole

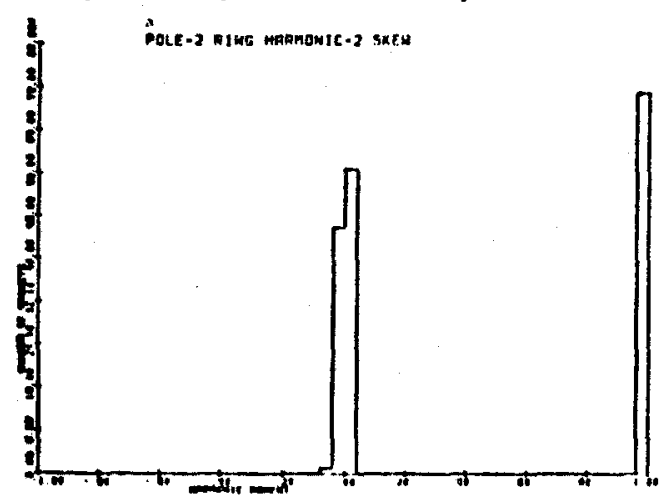

Figure 10: Skew Dipole moment of the dipole 


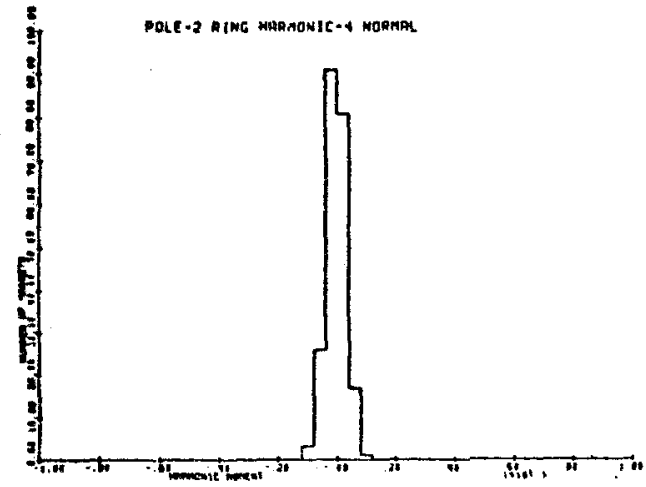

Figure 11: Quadrupole moment of the dipole

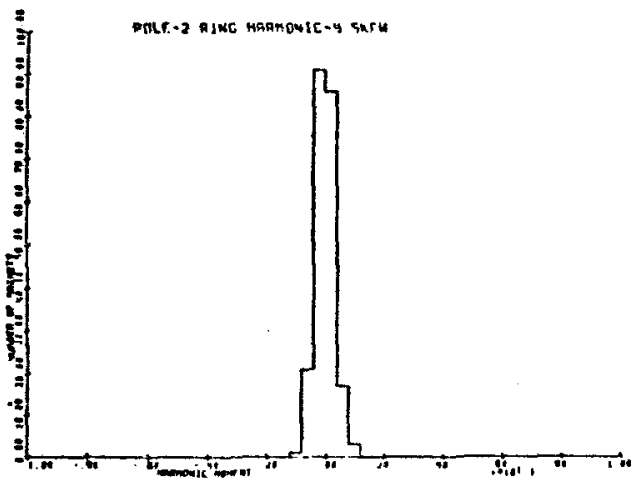

Figure 12: Skew quadrupole moment of the dipole

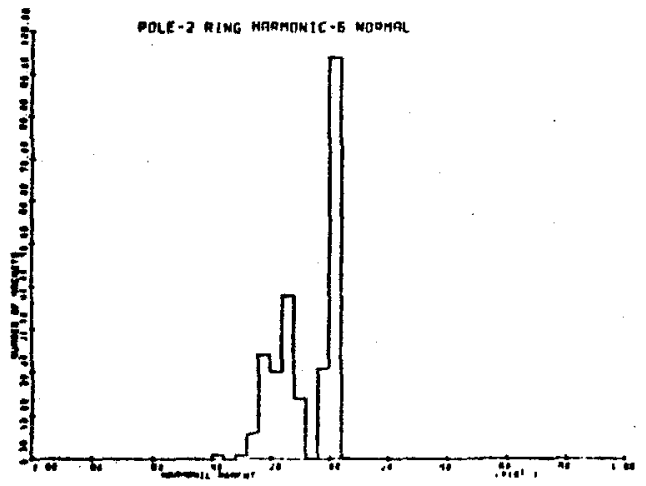

Figure 13: Sextupole moment of the dipole

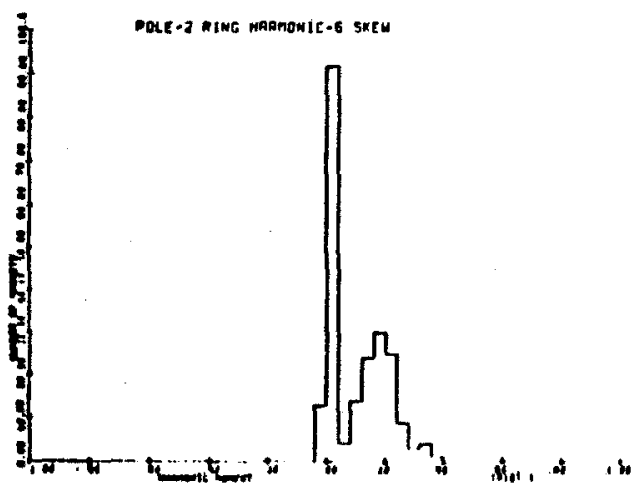

Pigure 14: Skew sextupole of the dipole moment

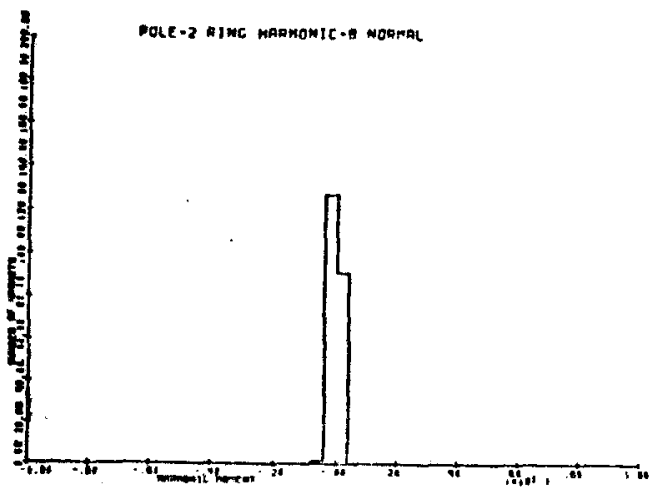

Figure 15: Octupole moment of the dipole DOLE-2 RIMG haAOW BC-A SXEU

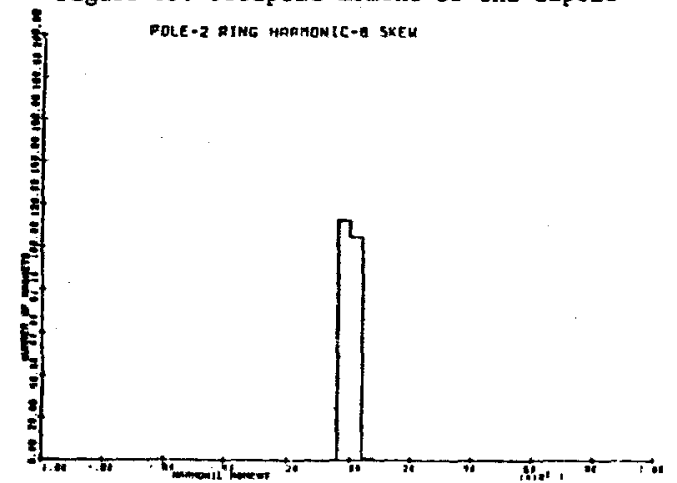

Figure 16: Skew octupole monent of the dipole

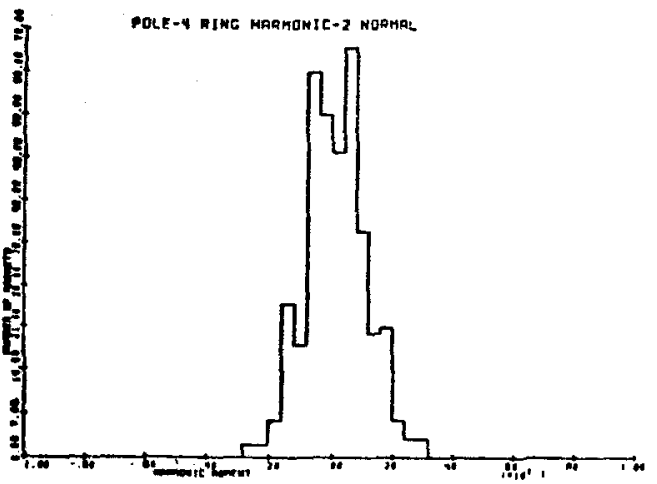

Figure 17: Dipole moment of the quadrupole

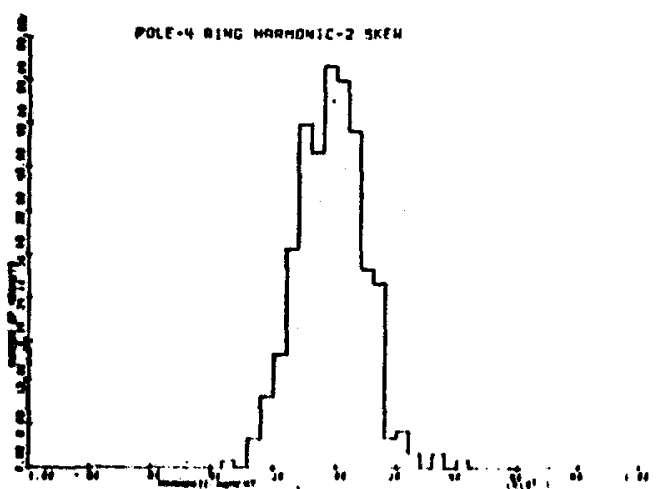

Igure 18: Skew dipole mument of the quadrupole 


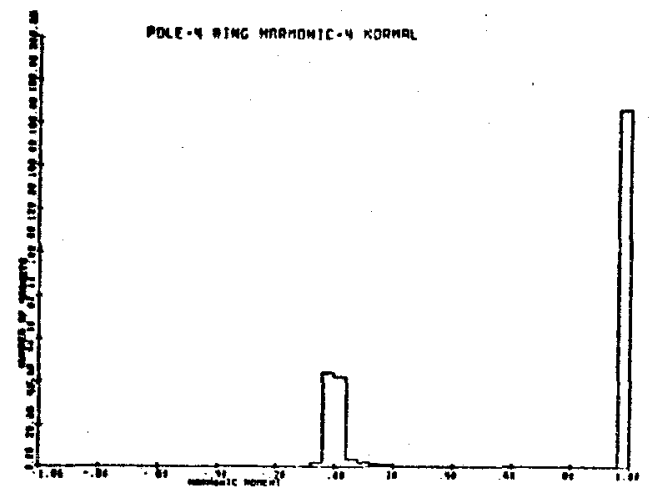

Figure 19: Quadrupole moment of the quadrupole

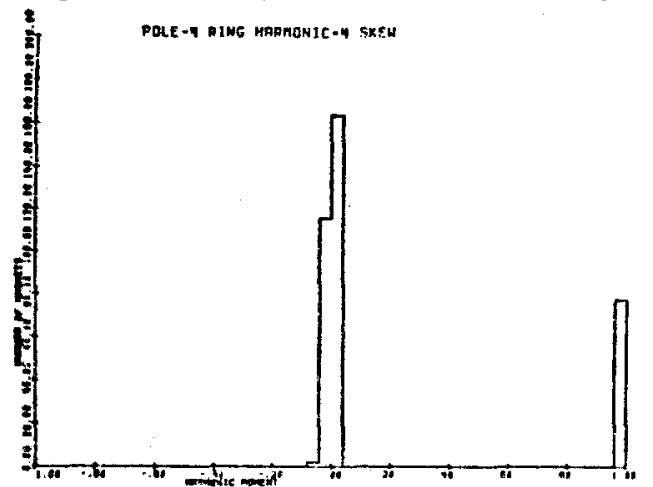

Figure 20: Skew quadrupole moment of the

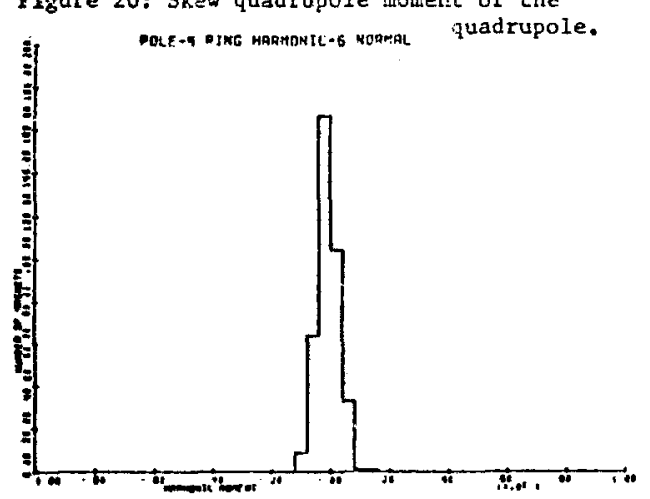

Figure 21: Sexsupole moment of the quadrupole

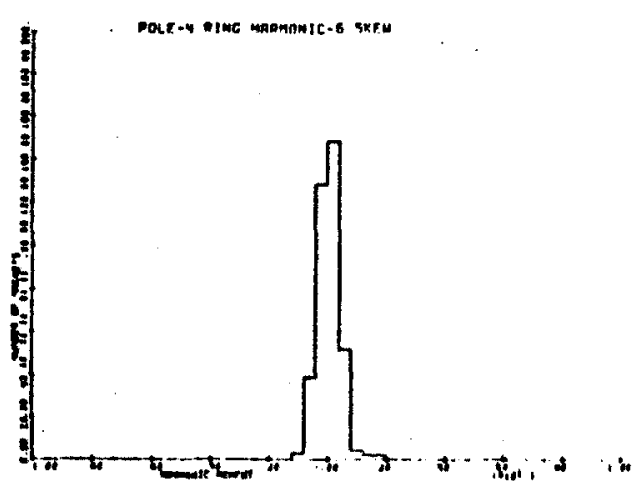

Nigure 22: Skew sextupole moment of the quadrupole

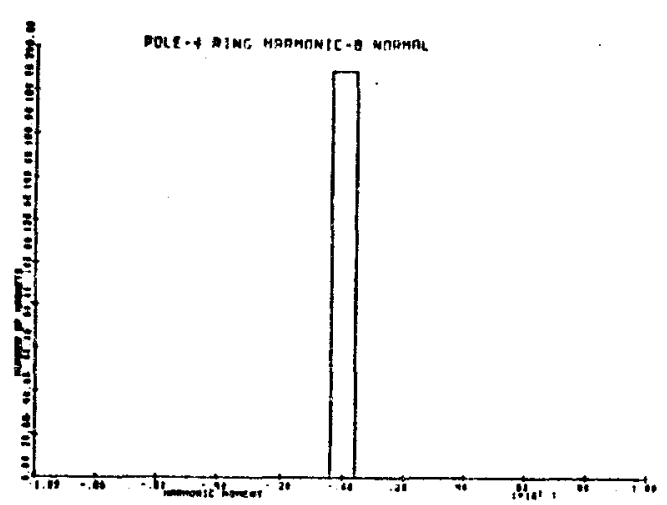

F1gure 23: Octupole moment of the quadrupole

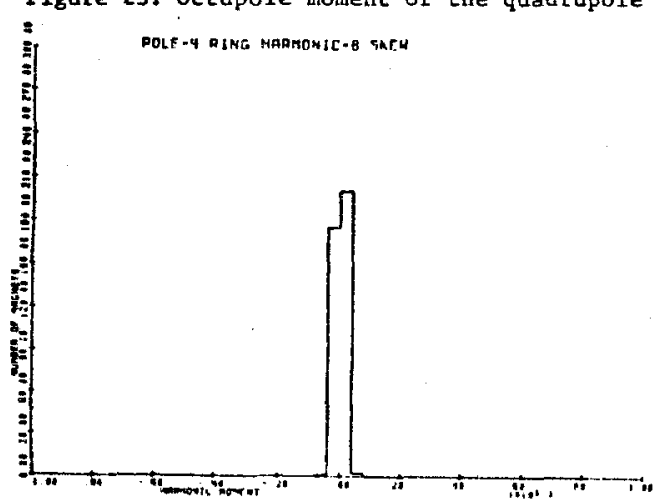

Figure 24: Skew octupole moment of the quadrupole DPLE-S RINE HARNANIC-2 NOOMAL

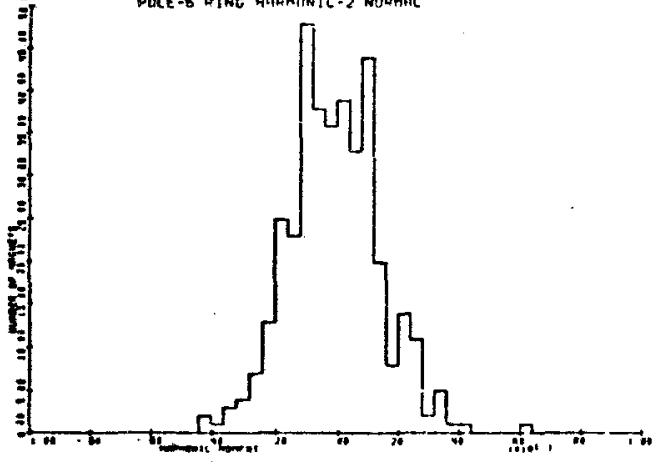

Figure 25: Dipole moment of the sextupole

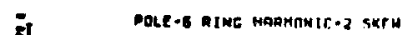

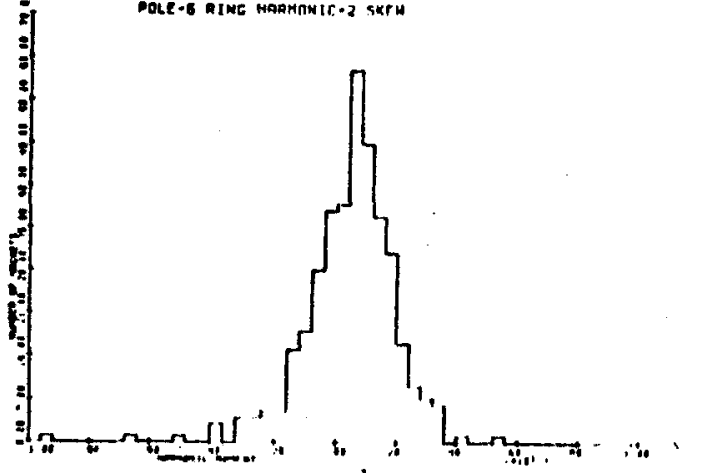

F1gure 26: Skew dipole of the sextupole 


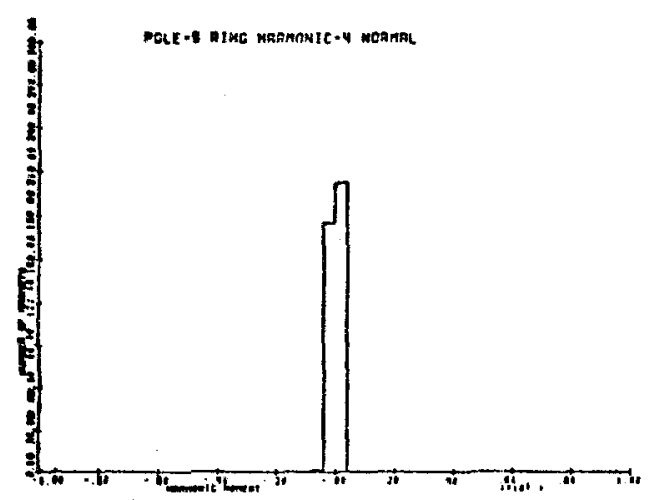

Figure 27: Octupole moment of the sextupole

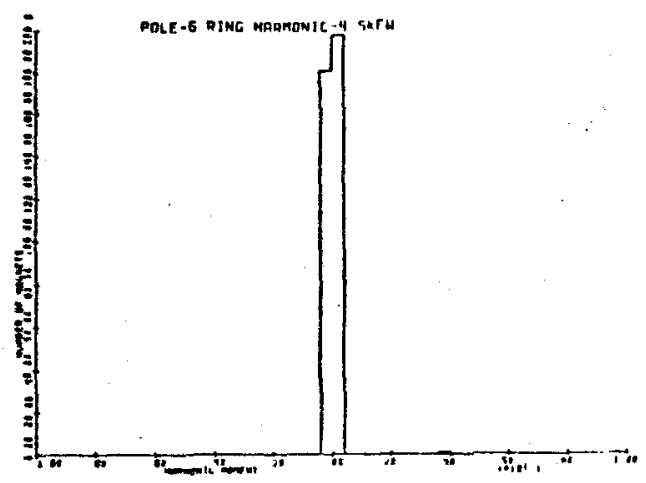

Pigure 28: Skew octupole moment of the sextupole

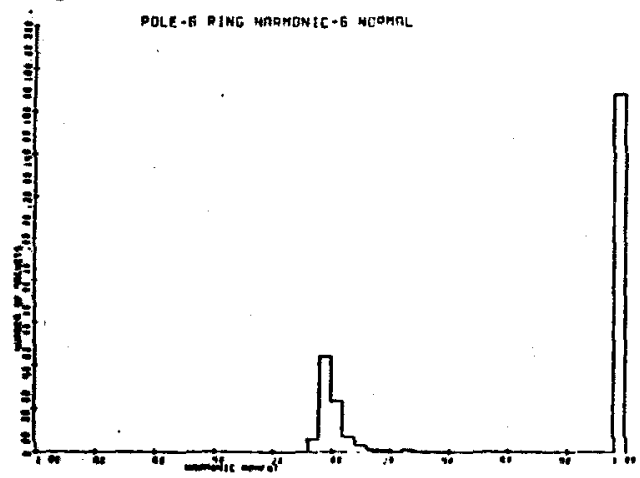

F1gure 29: Sextupole moment of the sextupole

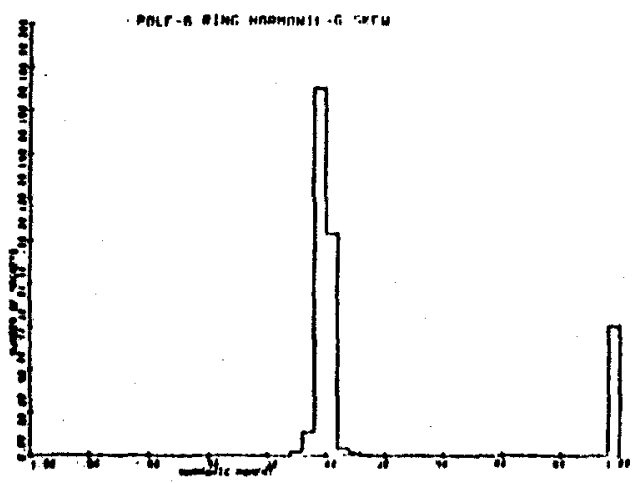

Fgure 30: Skew extupole moment of the sextupole.

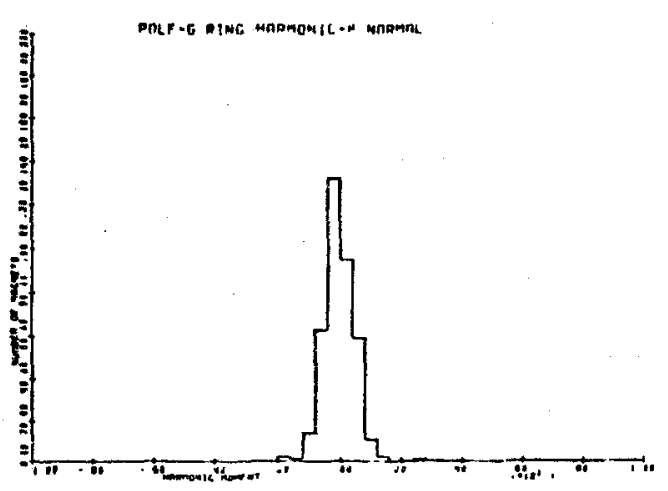

Figure 31: Octupole moment of the sextupole

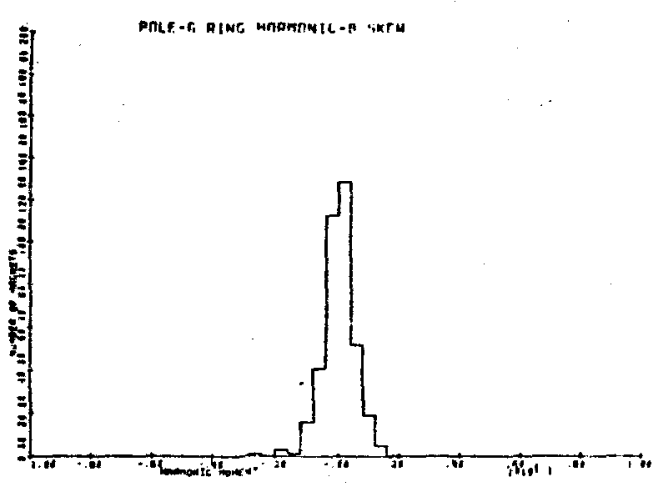

Figure 32: Skew octupole moment of the sextupole

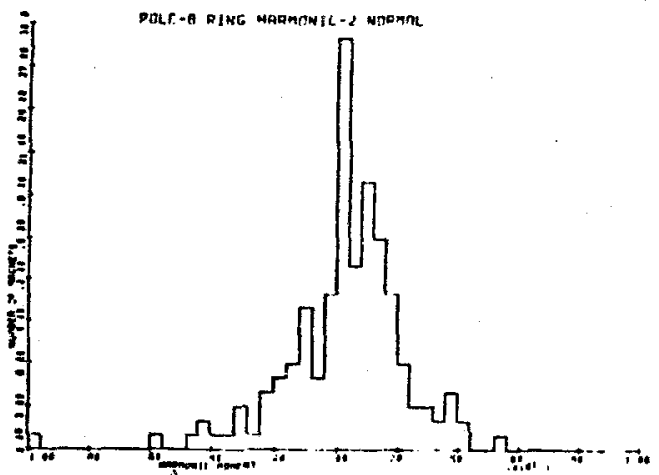

Pigure 33:" Dipole moment of the octupole

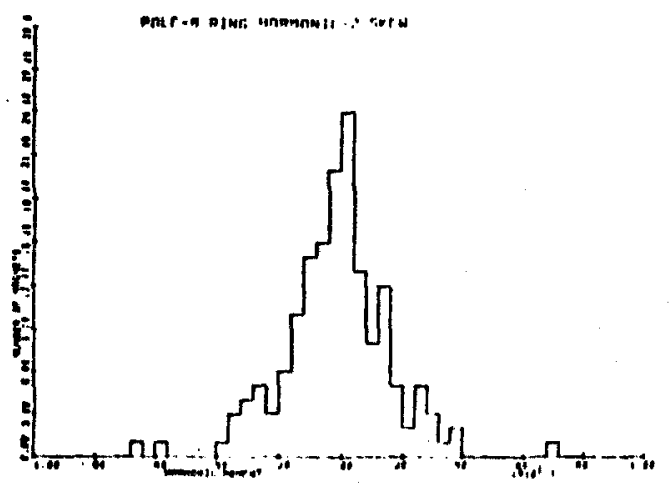

PIgure 34: Skew dipole moment of the octupole 


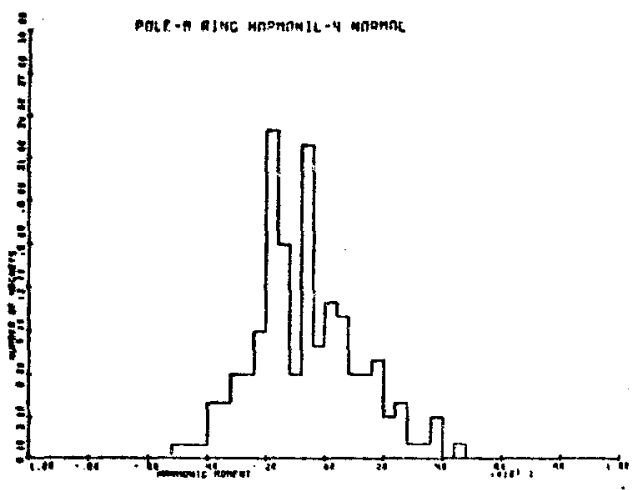

Figure 35: Quadrupole moment of the octupole

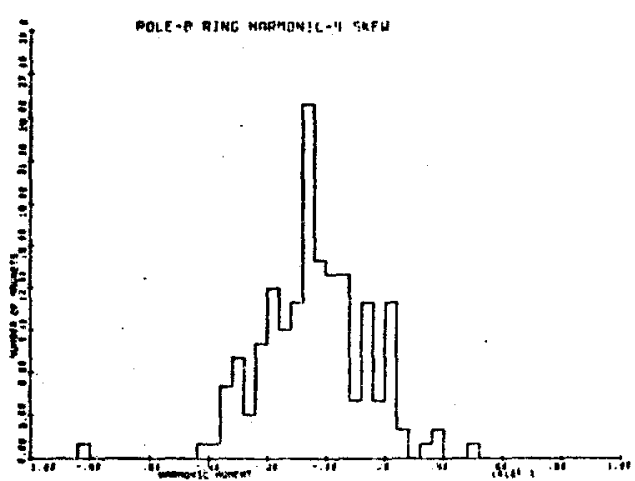

Figure 36: Skew quadrupole moment of the

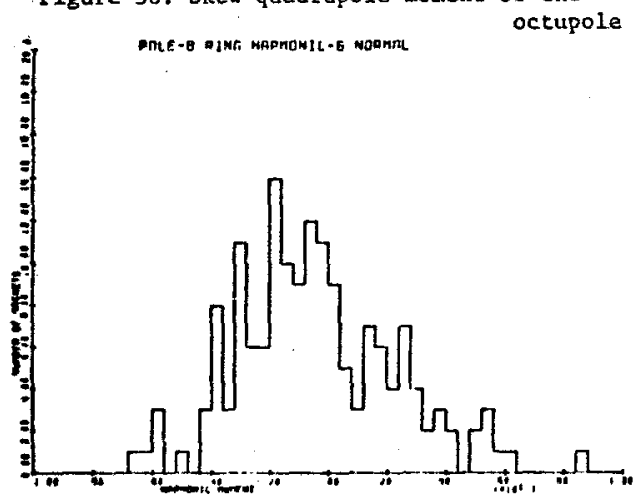

Figure 37: Sextupole moment of the octupole

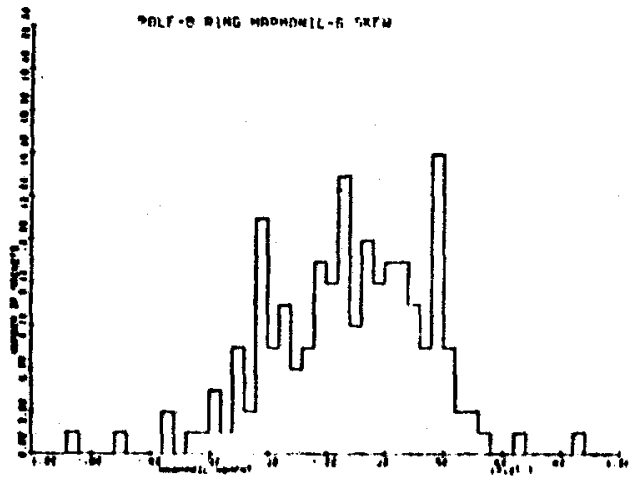

Figure 38: Skew sextupole moment of the octupole

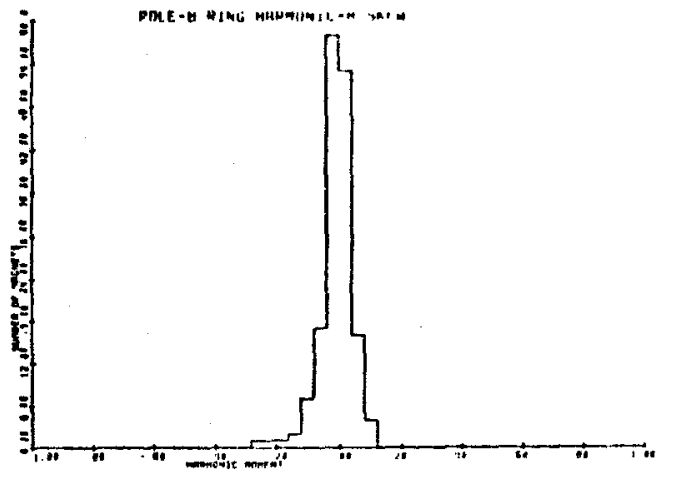

Figure 39: Skew octupole moment of the octupole

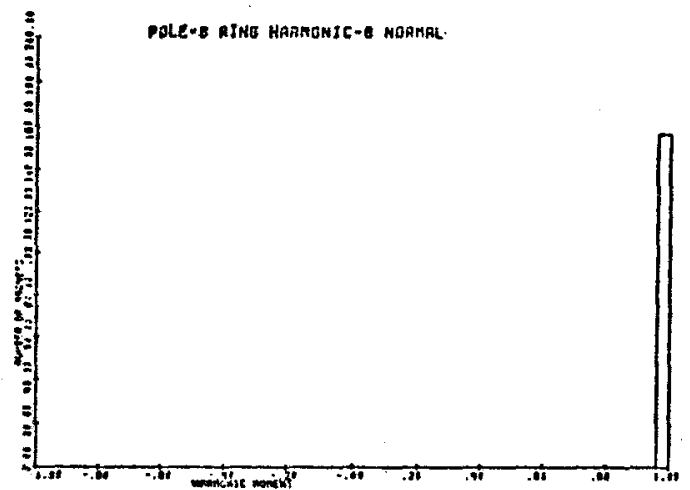

Figure 40: Octupole moment of the octupole

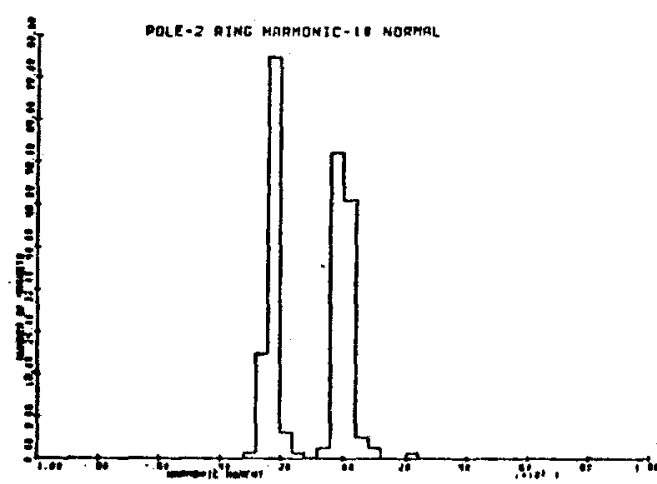

F1gure 41: Decapole moment of the dipole

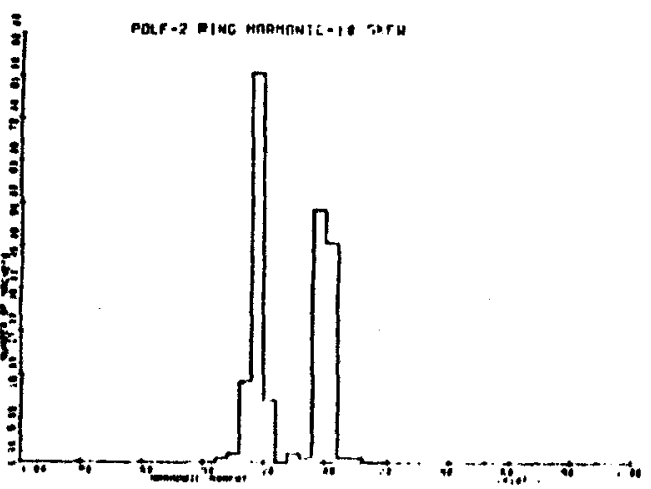

Flgure 42: skew decapole moment of the dipole 


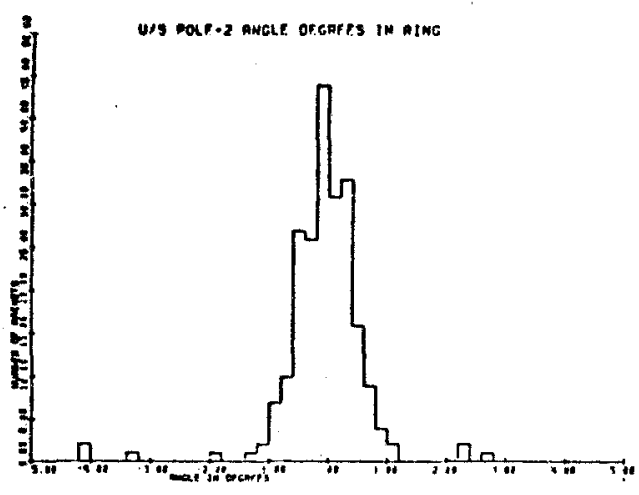

FIgure 43: Upstream dipole (DSQ) angle.

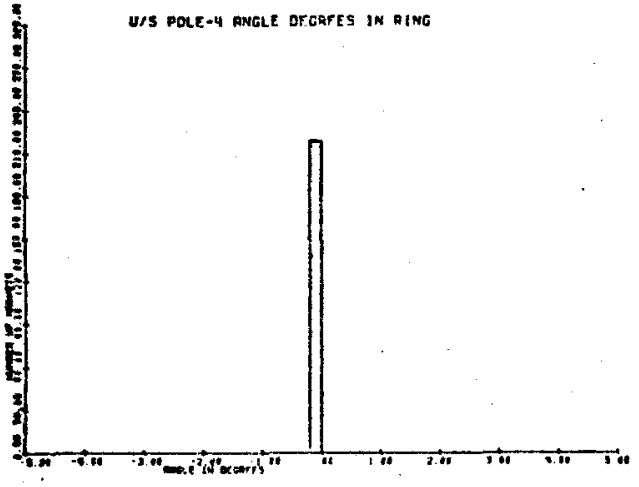

Figure 44: Upstrean quadrupole (DSQ) angle

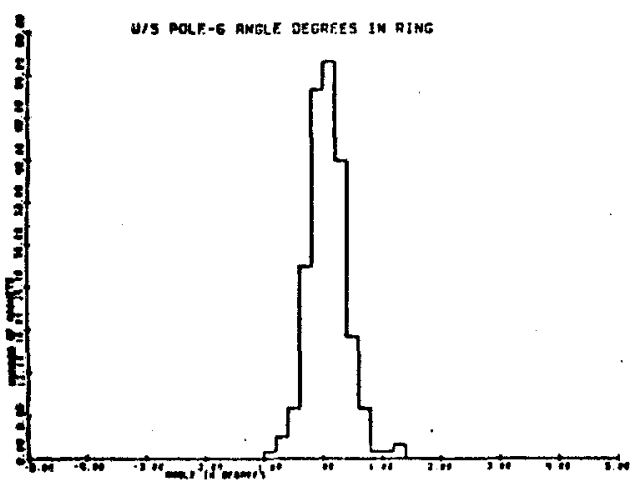

Figure 45: Upstream sexiupole (DSQ) angle

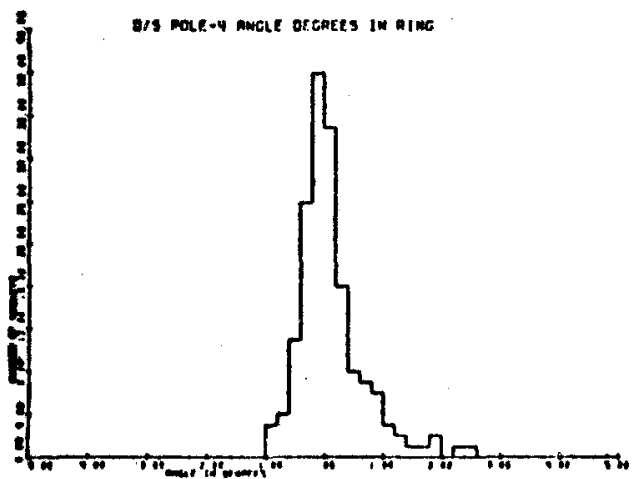

Figure 46 , Downstream quadrupole (OSO) angle

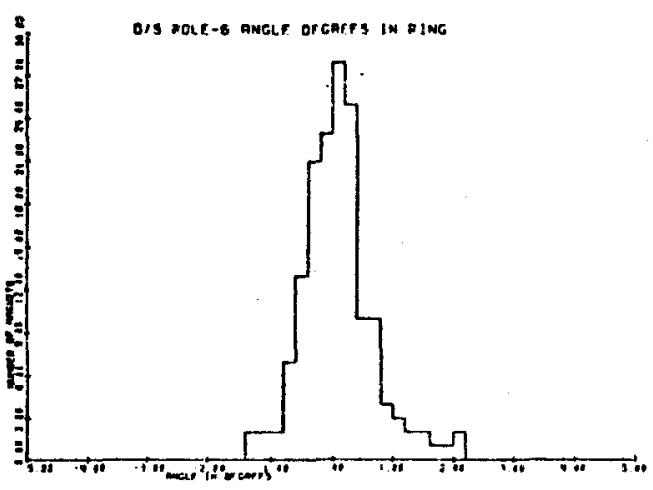

Figure 47: Dowastream sextupole (OSQ) angle

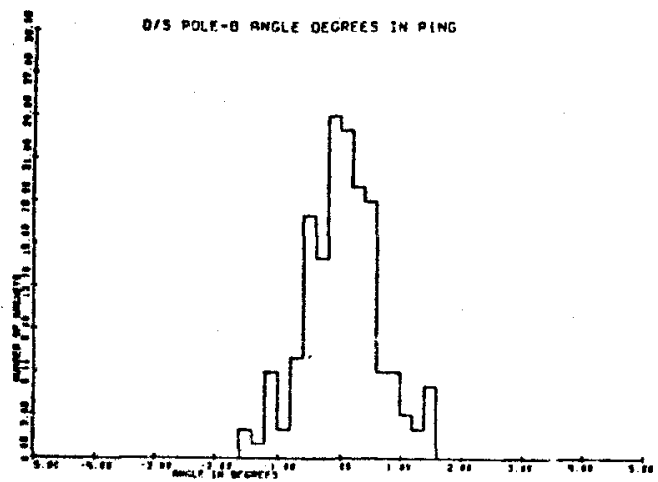

Figure 48: Downstream octupole (OSQ) angla 